\title{
On the hoof: exploring the supply of animals to the Roman legionary fortress at Caerleon using strontium $\left({ }^{87} \mathrm{Sr} /{ }^{86} \mathrm{Sr}\right)$ isotope analysis
}

\author{
Richard Madgwick $^{1}$ (D) $\cdot$ Jamie Lewis $^{2} \cdot$ Vaughan Grimes $^{3} \cdot$ Peter Guest $^{1}$
}

Received: 22 June 2017 / Accepted: 5 September 2017 /Published online: 22 September 2017

(C) The Author(s) 2017. This article is an open access publication

\begin{abstract}
Provisioning large concentrations of professional soldiers in Britain after the invasion in AD 43 was a major challenge for the Roman imperial administration. In a distant frontier province such as Britannia, it is generally believed that locally produced agricultural resources must have been vital in feeding and maintaining the occupying army, but direct evidence for this is limited. This study explores the potential for strontium isotope analysis $\left({ }^{87} \mathrm{Sr} /{ }^{86} \mathrm{Sr}\right)$ of faunal dental enamel to provide new insights for the provisioning of animals to the legionary fortress at Caerleon in South East Wales. Results from 37 domestic animals (cattle, caprines and pigs) from the recent excavation of a military store building in Caerleon are presented. Thirteen faunal dentine and modern plant samples were also analysed to characterise baseline signals for the local landscape. These results indicated an unexpectedly wide range of bioavailable ${ }^{87} \mathrm{Sr} /{ }^{86} \mathrm{Sr}$ in the local area, meaning identifying allochthonous individuals with confidence is difficult. The faunal dataset is also very wide ranging, but at least seven individuals can be identified as originating from beyond the local region, with some likely being brought from a substantial distance away. It is highly likely, however, that this underestimates the proportion of animals reared outside the fortress' immediate hinterland and individuals that fall within the diverse local range could also have been from
\end{abstract}

Richard Madgwick

madgwickrd3@cardiff.ac.uk

1 School of History, Archaeology and Religion, Cardiff University, John Percival Building, Colum Drive, Cardiff CF10 3EU, UK

2 School of Chemistry, University of Bristol, Cantock's Close, Clifton, Bristol BS8 1TS, UK

3 Department of Archaeology, Memorial University of Newfoundland, 210 Prince Philip Drive, St. John's, NF A1C 5S7, Canada further afield. This has implications for understanding how the Roman legion was sustained, as well as the impact that provisioning the army had on the countryside, particularly around military sites.

Keywords Roman army · Strontium isotope analysis · Provisioning $\cdot$ Biosphere mapping

\section{Introduction}

\section{Provisioning the Roman army}

The Romans' success as empire builders is in a very large way explained by their capacity to concentrate large numbers of professional, well-equipped soldiers against their enemies for long periods of time. By the middle of the first century AD, the Roman Empire had grown to extend from Britain in the north to Egypt in the south and from Syria in the east to the Atlantic coast in the west. It is estimated that the army at this time comprised some 300,000 men, of whom about 40,000 invaded Britain in AD 43. Over the following decades, all of the native tribes in modern-day England and Wales were incorporated into the new province of the Roman Empire, some by force of arms and others by treaty. The invaders found the natives in Wales particularly troublesome and for some 40 years or so after their final subjugation between $73 / 74$ and 77/78 an estimated 25,000 Roman soldiers were garrisoned in this part of western Britain (estimated to represent between 10 and $17 \%$ of the total population) (Mattingly 2006, pp. 101-16; Arnold and Davies 2000, pp. 3-24; Burnham and Davies 2010, pp. 37-48 and 137-45).

The ability to maintain a standing army on this scale and over such a wide area is one of the defining characteristics of the Roman period, and understanding exactly how the soldiers 
were supplied and provisioned has become an increasingly important question. For many years, the ancient literature was the only source of relevant evidence, but from the 1970s, new information regarding the consumption of animals began to come from the nascent science of zooarchaeology (Davies 1971; Labisch 1975; Dickson 1989; King 1984). As excavators realised the potential of animal bones, the analysis of faunal remains resulted in the correction of oft-repeated misconceptions (for example, that Roman soldiers were largely vegetarian), as well as significant new insights based on species and ageing data. The past 50 years have witnessed a surge in the study of animal bone assemblages from Roman military sites, and today, we have a far better appreciation of the army's use and consumption of animals, particularly cattle, sheep/goats and pigs (King 1999; King 2001; Stallibrass and Thomas 2008; Stallibrass 2009; Maltby 2016). Remains of the three major domesticated animal species dominate the zooarchaeological record of the army and it is widely accepted that Roman soldiers enjoyed a relatively meat-rich diet, at least when compared to the majority of the population at the time. It should not be forgotten, however, that these animals also produced other foods (milk and cheese), as well as essential resources such as leather, skins and wool.

Despite the accumulation of new material and analysis, we still have only a very rudimentary understanding of the quantities of animals consumed by Roman military units, where and by whom these were reared, or how their supply was organised. The assumption that most cattle, sheep/goats and pigs would have been bred and reared locally, in part by the army itself or requisitioned from the local population, forms the basis of most recent academic discussions, whether historical or archaeological (Carreras Monfort 2002; Herz 2002; Junkelmann 1997, pp. 154-63; Kehne 2007; Mason 1988; Pearce 2002; Roth 1999, pp. 117-55; Thomas and Stallibrass 2008; Whittaker 2002). If this notion is correct, the presence of a sizeable military garrison will have had a presumably significant (though as yet unquantified) impact on the inhabitants of recently conquered territories, most especially in the countryside around the army's forts and fortresses. Simply feeding the 5500 men in a Roman legion, for instance, must have required the ability to control agricultural resources over a wide area and to organise their redistribution from producers to consumers quickly and effectively. Yet, how the Roman authorities were able to make this happen is almost entirely unknown (though see Thomas (2008), Cavallo et al. (2008) and Groot (2008) for examples of zooarchaeological approaches to this question).

In part, this lack of understanding is because the surviving ancient sources did not generally concern themselves with the day-to-day routines of the army. Meanwhile, even though the archaeological evidence for the eating and drinking habits of Roman soldiers is varied and plentiful, until recently, there have been few attempts to integrate the study of pottery, animal bones and other environmental remains in order to address wider questions of the military diet, or where and how the cereals, vegetables, fruit and meat consumed in Roman forts and fortresses were produced (Cool 2006, p. 1). The significance of this topic has long been recognised and in 2002, Richard Reece stated: 'The huge quantity of resources needed by the army and the impact this might have had on the local native populations seem to me to be areas which cry out for investigation' (Reece 2002, p. 187).

The development of isotope analysis and its application to animal bone assemblages from archaeological contexts has the potential to transform the study of the provisioning of the Roman army. The analysis of isotopic ratios in bones and teeth can be used to reconstruct diet (carbon and nitrogen), geographic origin and palaeoenvironment (oxygen and strontium). Strontium in particular can provide direct evidence for nonlocal individuals and should prove useful for reconstructing the supply networks that supported military sites. This can in turn provide insights into the nature of the developing relationships between the Roman invaders and the populations of conquered territories.

Isotope provenancing techniques have been commonly applied to a Romano-British material in recent years, although research has principally focused on humans (Chenery et al. 2010; Chenery et al. 2011; Eckardt et al. 2009; Leach et al. 2009; Montgomery et al. 2010a; Montgomery et al. 2011; Müldner et al. 2011; Redfern et al. 2016; Shaw et al. 2016). Studies of faunal remains are very rare, and to date, only a single isotope study that addresses livestock supply in Roman Britain has been published and this dealt with a rural settlement rather than a military site. The study by Minniti et al. (2014) compared patterns in the movement of cattle to the site of Owslebury in Hampshire from the Middle Iron Age to the later Roman period. The research identified a greater diversity of results during the Roman occupation that, it was suggested, indicates an increase in the supply of livestock from a wide range of locations beyond the local area. Although the paper did not explore origins in detail, some cattle from Owslebury must have moved substantial distances to reach the site, perhaps over more than $70 \mathrm{~km}$. This provides important insights into the scale and volume of livestock movement in Roman Britain and hints at the potential of an isotope study for investigating the provisioning of the Roman army.

\section{Feeding the legion at Caerleon}

The native tribes of what is now Wales were renowned for their stubborn opposition to Roman expansion, occupying much of the army in Britain from 47/8 to their final conquest in 77 or 78. The Silures of South Wales gained a reputation for their particularly implacable resistance, leading the Roman writer Tacitus to record that 'on the Silures neither terror nor 
mercy had the least effect; they persisted in war and could be quelled only by legions encamped in their country' (Annals 12,32 ). Ultimately, however, the Silures and the other tribes of Wales were defeated and their lands occupied. An estimated 25,000 Roman soldiers would be garrisoned in Wales for the next 30 to 40 years before many of the troops were subsequently withdrawn to construct and man Hadrian's Wall in northern Britain from the 120s (Burnham and Davies 2010, pp. 37-48 and 137-45).

Two full legions formed the backbone of this short-lived frontier in Wales, based on their fortresses at Isca (Caerleon) in the south and Deva (Chester) in the north. Both fortresses were strategically sited on the lower reaches of important rivers (the Usk and the Dee respectively), controlling the coastal routes into and out of Wales while also connecting the legions to the rest of Britain as well as other parts of the Roman Empire. Although both fortresses have been the focus of archaeological excavations for many years, unlike Chester, large parts of the fortress at Caerleon are free of later buildings, thus giving archaeologists more opportunities to explore the site's history and that of its legionary garrison, the Second Augustan Legion (Legio Secunda Augusta). Mortimer Wheeler's excavation of the amphitheatre in the 1920s was the first scientific archaeological investigation of the site, after which further excavations, often over large areas, were undertaken in and around Caerleon throughout much of the twentieth century. Recent work has provided a great deal of new information about Isca, particularly the early decades after its foundation in the mid-1970s when the fortress was probably often occupied by only a skeleton garrison, while most of the legion was occupied elsewhere building roads, forts, bridges, new towns and cities, or frontier walls (Boon 1987; Breeze 2002; Jarrett 2002; Evans 2010).

Caerleon is one of the most studied and best understood legionary fortresses anywhere in the Roman Empire, yet we have very little idea about how the Second Augustan Legion was supplied. Some foodstuffs came from other parts of the Empire (notably wines from Italy and Spanish olives and olive oil), but it has always been assumed that the daily staples must have originated locally (Davies 2004; Mason 1988). However, this is little more than educated guesswork and, in reality, where and how grain for bread and fodder was grown, or the cattle for beef, milk and leather, and the sheep for mutton and wool were reared, are questions to which we did not have the means to provide reliable answers (although reclamation of the Gwent Levels is thought to have possibly been for the pasturing of the legionary cattle herd, see Fulford 2002, pp. 85-86).

The animal bones analysed in this study were recovered during excavations in 2008 and 2010 of the remains of a military store building in Priory Field (Gardner and Guest 2013; Guest and Gardner 2017, see Fig. 1 for location). These produced a large faunal assemblage including 9413 stratigraphically phased specimens, of which 2964 originated in deposits related to the construction, use, and collapse of the store, as well as its re-use in the centuries after the Roman period (Andrews et al. 2013). Samples were selected from the following phases of Roman and post-Roman occupation:

- 0ii Pre-store building — site clearance and/or pre-construction dumping (pre-AD 90)

- 1 ii Construction-levelling and floors (c. 90-110)

- 2 Use - occupation of store building (c. 110-350)

- 3 Disuse - decay and demolition (c. 350-430+)

- 4 Re-use - new masonry building (c. 430-600)

The Priory Field faunal assemblage is overwhelmingly dominated by domesticates and this study focuses on the origins of the main three domestic food taxa: cattle, pigs and caprines (sheep/goats). In general, the assemblage is noteworthy for having a smaller proportion of caprines than is common for Roman military sites, a feature King (1999) has suggested might indicate a more Gallic-style diet. The bulk of the sampled animal bones is from phase 1ii deposits and most likely date to the later first or early second centuries (phase 1ii produced more bone overall than any other) (see Table 1). Samples from the post-Roman reoccupation (phase 4) are stratigraphically less secure, and there is a distinct possibility that these bones are residual from the store's abandonment, decay and collapse/demolition (phase 3).

\section{Materials and methods}

\section{Samples}

A total of 44 animals were analysed ( 23 cattle, 10 caprines and 11 pigs, Table 1). Given the complexities of identifying caprine dentition to precise species (Zeder and Pilaar 2010), all sheep/goat specimens have been assigned to the taxonomic category of caprine. Ideally, sampling would repeatedly target the same-sided tooth for all individuals of each taxon to ensure that all samples represent separate individuals. However, this was rarely possible due to the limited numbers of suitable samples securely assigned to a single phase $(0-4)$. Measures were taken to reduce the chance of repeat sampling of the same individual when available specimens allowed, by assessing morphology, context, dental attrition and element side. On the balance of probability, the likelihood of repeat sampling at a legionary fortress like Caerleon is very low, but it cannot be entirely discounted.

Analysis was undertaken as part of two separate projects. For the first 30 samples (CPF01-CPF30), the programme of analysis aimed to reconstruct early life origins and therefore enamel from early developing teeth was targeted. Enamel was generally extracted from close to the occlusal surface, but in 
Fig. 1 Location map of Caerleon

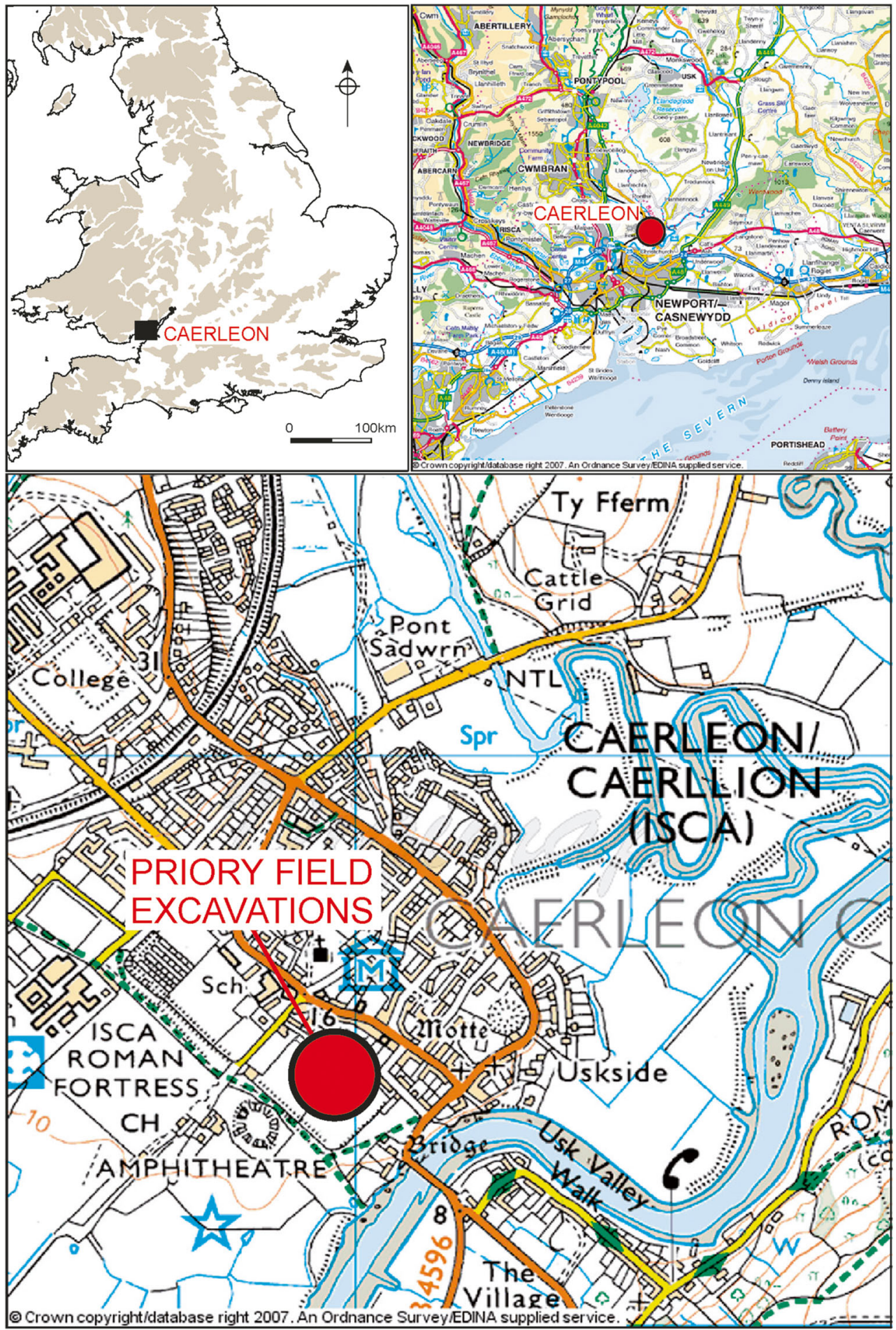

some early developing teeth (M1 or dp4), enamel from closer to the root-enamel junction (REJ) was sampled, so that specimens did not represent radically different periods in the animals' lives. Where preservation allowed, the buccal surface of distal cusp units (in the case of molars) was sampled. Only teeth that showed wear were used, as these would be highly or fully mineralised and therefore more resistant to diagenetic alteration. The second project sampled CPF31-CPF37 as part of a separate methodological study (Lewis et al. 2017) and involved a different sampling strategy. For these samples, enamel was taken from the full growth axis (from the REJ to the occlusal surface) and ratios represent an averaged signal from across the crown. Details of the samples are presented in Table 2. 
Table 1 Animals sampled from the Priory Field excavations in Caerleon

\begin{tabular}{llll}
\hline Phase & Cattle & Caprine & Pig \\
\hline 0ii (pre-AD 90) & 2 & 0 & 0 \\
1ii (c. $90-110)$ & 12 & 8 & 5 \\
2 (c. $110-350)$ & 2 & 1 & 2 \\
3 (c. $350-430+)$ & 2 & 0 & 2 \\
4 (c. $430-600)$ & 5 & 1 & 2 \\
Total & 23 & 10 & 11 \\
\hline
\end{tabular}

In addition, six modern plant samples were collected from the major geological units around Caerleon, to assist with defining the locally bioavailable ${ }^{87} \mathrm{Sr} /{ }^{86} \mathrm{Sr}$ range (see Fig. 2). All were leaf samples from hedgerows taken from locations away from main roads and farms, thus minimising the potential for contamination (coordinates for the location of the plants along with bedrock geological information and ${ }^{87} \mathrm{Sr} /{ }^{86} \mathrm{Sr}$ isotope results are presented in Table 3).

These plants were supplemented by seven dentine specimens (paired to the CPF31-CPF37 enamel samples) analysed to characterise the local diagenetic signal of the soil in Caerleon (CPF38-CPF44, Table 2).

\section{Methods}

Strontium $\left({ }^{87} \mathrm{Sr} /{ }^{86} \mathrm{Sr}\right)$ isotope analysis was employed to identify animals that were not locally reared and to explore potential areas of origin. The approach has been used extensively on humans, but in recent years, methodological research (e.g. Madgwick et al. 2012; Montgomery et al. 2010b) and case studies (e.g. Bendrey et al. 2009; Towers et al. 2010; Viner et al. 2010) have demonstrated the value of the method for examining the movement of domestic animals in Britain.

The approach has been explained in detail elsewhere (e.g. Bentley 2006; Buzon et al. 2007; Price et al. 2002) and is therefore only briefly described here. Strontium isotope analysis relies on the premise that the bioavailable strontium from the region where a human or animal is sourcing their diet is incorporated into their bodily tissues (including bones and teeth) through the food chain. Strontium substitutes for calcium in the hydroxyapatite of bone and teeth (Bentley and Knipper 2005). Bone and dentine are relatively porous and have low crystallinity and are therefore not suitable for analysis, as biogenic signatures will be contaminated by the burial environment (Price et al. 1992; Trickett et al. 2003; Hoppe et al. 2003). However, dental enamel, which is used in this study, has been shown to be more resistant to diagenetic alteration and to retain biogenic strontium (Budd et al. 2000). However, it is still subject to some diagenetic alteration (Madgwick et al. 2012). Underlying geology has the greatest effect on bioavailable strontium isotope values, with the geological ${ }^{87} \mathrm{Sr} /{ }^{86} \mathrm{Sr}$ controlled by the rubidium (Rb)-to-strontium ratio and the age of the rock. However, precipitation also has an impact, especially in areas with high rainfall such as on the western seaboard of Britain (Evans et al. 2010). The strontium isotope value of rainfall, which derives from seawater, is 0.70918 (McArthur et al. 2001; Pearce et al. 2015), and thus falls within the most common biosphere package in Britain (Evans et al. 2010). In saturated soils, this rainfall-derived strontium will have a diluting effect on geologically derived values, complicating the interpretation of biogenic strontium isotope signals. In addition, interpretation is hindered by the relatively coarse biosphere maps that are generally available. The work by Evans et al. (2010) has greatly improved the situation in Britain, but biosphere mapping remains far from comprehensive.

The majority of analysis was undertaken at the Memorial Applied Archaeological Sciences Laboratory of Memorial University of Newfoundland (CPF01-CPF30), with seven paired enamel and dentine, and all plant samples analysed at the Bristol Isotope Group Laboratory at the University of Bristol. Enamel and dentine samples (10-50 mg) were cut from teeth and cleaned using a diamond saw and burr to remove all adhering dentine from enamel samples and at least $10 \mu \mathrm{m}$ of the enamel surface. Sample chemistry at the Memorial University of Newfoundland and University of Bristol follows a common and well-defined methodology. Enamel samples were cleaned with high-purity (99\%) acetone followed by deionised water ( $\mathrm{DI}_{2} \mathrm{O},>17 \mathrm{M} \Omega$ ) and dried down. Plant samples were washed in DI water, dried and crushed to tea leaf consistency following Evans et al. (2010). Samples were then weighed into clean perfluoroalkoxy (PFA) vials.

Enamel samples were dissolved in high-purity $\mathrm{HNO}_{3}$ on a hot plate. Plant samples $(0.1 \mathrm{~g})$ were sequentially treated with high-purity $\mathrm{HNO}_{3}, \mathrm{HNO}_{3}: \mathrm{HCl}, \mathrm{HNO}_{3}: \mathrm{H}_{2} \mathrm{O}_{2}$ and $\mathrm{HNO}_{3}: \mathrm{HClO}_{4}$ on a hot plate. Strontium extraction in both laboratories used Sr-Spec ${ }^{\mathrm{TM}}$ resin (Eichrom, Horwitz et al. 1992) and followed a common procedure for strontium purification. Approximately $100 \mu \mathrm{l}$ of pre-cleaned $\mathrm{Sr}-\mathrm{Spec}$ resin is loaded into extraction columns, and samples were then loaded on to the resin in nitric acid, either $0.5 \mathrm{ml}$ of $3 \mathrm{M} \mathrm{HNO}_{3}$ or $1 \mathrm{ml}$ of $6 \mathrm{M} \mathrm{HNO}_{3}$ in the University of Bristol and Memorial University of Newfoundland, respectively. Matrix elements were then eluted in 3 column volumes of $\mathrm{HNO}_{3}$, and purified strontium fractions were then collected in 2 column volumes of DI $\mathrm{H}_{2} \mathrm{O}$ ready for mass spectrometry.

At the Memorial University of Newfoundland, strontium isotope ratios were measured using a Thermo Finnigan Neptune multi-collector inductively coupled mass spectrometer (MC-ICP-MS) in the CREAIT facility. All data was first corrected for on on-peak blank intensities and then mass bias corrected using the exponential law and a normalisation ratio of 8.375209 for ${ }^{88} \mathrm{Sr} /{ }^{86} \mathrm{Sr}$ (Nier 1938). Residual krypton (Kr) 
Table 2 Details of analysed samples and ${ }^{87} \mathrm{Sr} /{ }^{86} \mathrm{Sr}$ isotope ratios

\begin{tabular}{|c|c|c|c|c|c|c|c|c|}
\hline $005 \mathrm{~A}$ & Taxon & Material & Context & Phase & Element & Sample position & ${ }^{87} \mathrm{Sr} /{ }^{86} \mathrm{Sr}$ & Precision (2 SE \%) \\
\hline CPF01 & Sus & Enamel & 2123 & 1 & Lower M2 & Low-mid cusp & 0.709276 & 0.0008 \\
\hline $\mathrm{CPF} 02$ & Sus & Enamel & 2123 & 1 & Lower P4 & Low-mid cusp & 0.709045 & 0.0012 \\
\hline CPF03 & Sus & Enamel & 2123 & 1 & Lower M2 & Mid cusp & 0.713743 & 0.0006 \\
\hline CPF04 & Sus & Enamel & 2080 & 2 & Lower M2 & Mid cusp & 0.713467 & 0.0009 \\
\hline CPF05 & Sus & Enamel & 2080 & 2 & Lower P4 & Mid cusp & 0.713277 & 0.0007 \\
\hline CPF06 & Sus & Enamel & 2100 & $1 / 2$ & Upper M1 & Lower cusp & 0.711954 & 0.0006 \\
\hline CPF07 & Sus & Enamel & 2061 & 3 & Upper M1 & Lower cusp & 0.709585 & 0.0007 \\
\hline CPF08 & Sus & Enamel & 3008 & 4 & Lower M2 & Low-mid cusp & 0.712083 & 0.0007 \\
\hline CPF09 & Sus & Enamel & 3008 & 4 & Upper P3 & Low-mid cusp & 0.713593 & 0.0008 \\
\hline CPF10 & Sus & Enamel & 2122 & 1 & Lower M2 & Mid cusp & 0.71285 & 0.0011 \\
\hline CPF11 & Bos & Enamel & 2122 & 1 & Lower M1/M2 & Mid cusp & 0.708244 & 0.001 \\
\hline CPF12 & Bos & Enamel & 614 & $1 / 2$ & Lower M1/M2 & Mid cusp & 0.711631 & 0.0005 \\
\hline CPF13 & Bos & Enamel & 2097 & 2 & Lower P3 & Mid cusp & 0.708707 & 0.001 \\
\hline CPF14 & Bos & Enamel & 2100 & $1 / 2$ & Lower M1/M2 & Mid cusp & 0.710346 & 0.0007 \\
\hline CPF15 & Bos & Enamel & 3008 & 4 & Upper M1/M2 & Mid cusp & 0.709295 & 0.0009 \\
\hline CPF16 & Bos & Enamel & 3008 & 4 & Upper M1/M2 & Mid cusp & 0.709277 & 0.0007 \\
\hline CPF17 & Bos & Enamel & 2061 & 3 & Upper P4 & Mid cusp & 0.710756 & 0.0007 \\
\hline CPF18 & Bos & Enamel & 3008 & 4 & Lower P4 & Mid cusp & 0.71228 & 0.0008 \\
\hline CPF19 & Bos & Enamel & 2122 & 1 & Upper M1/M2 & Mid cusp & 0.709184 & 0.0005 \\
\hline CPF20 & Bos & Enamel & 2097 & 2 & Lower P4 & Mid cusp & 0.712933 & 0.0008 \\
\hline CPF21 & Caprine & Enamel & 2122 & 1 & Lower M1/M2 & Mid cusp & 0.709276 & 0.0008 \\
\hline CPF22 & Caprine & Enamel & 2123 & 1 & Upper M1/M2 & Mid cusp & 0.708861 & 0.001 \\
\hline CPF23 & Caprine & Enamel & 2149 & 1 & Upper M1/M2 & Mid cusp & 0.709486 & 0.0006 \\
\hline CPF24 & Caprine & Enamel & 2123 & 1 & Upper M3 & Mid cusp & 0.708337 & 0.0006 \\
\hline CPF25 & Caprine & Enamel & 3089 & 1 & Upper M1/M2 & Mid cusp & 0.709777 & 0.0007 \\
\hline CPF26 & Caprine & Enamel & 614 & $1 / 2$ & Lower M3 & Upper cusp & 0.709256 & 0.0006 \\
\hline CPF27 & Caprine & Enamel & 614 & $1 / 2$ & Lower dp4 & Lower cusp & 0.709541 & 0.0007 \\
\hline CPF28 & Caprine & Enamel & 605 & 2 & Upper M1/M2 & Mid cusp & 0.711728 & 0.0008 \\
\hline CPF29 & Caprine & Enamel & 2097 & 2 & Lower dp4 & Lower cusp & 0.714719 & 0.0011 \\
\hline CPF30 & Caprine & Enamel & 3008 & 4 & Upper M1/M2 & Mid cusp & 0.710212 & 0.001 \\
\hline CPF31 & Bos & Enamel & 2122 & 1 & M1 & Full axis & 0.709169 & 0.0006 \\
\hline CPF32 & Bos & Enamel & 2123 & 1 & M3 & Full axis & 0.71303 & 0.0006 \\
\hline CPF33 & Bos & Enamel & 2140 & 1 & $\mathrm{M} 1 / \mathrm{M} 2$ & Full axis & 0.715124 & 0.0006 \\
\hline CPF34 & Bos & Enamel & 3008 & 4 & M1 & Full axis & 0.709284 & 0.0006 \\
\hline CPF35 & Bos & Enamel & 3115 & 0ii & M3 & Full axis & 0.710272 & 0.0006 \\
\hline CPF36 & Bos & Enamel & 610 & 2 & M2 & Full axis & 0.709568 & 0.0005 \\
\hline CPF37 & Sus & Enamel & 2123 & 1 & $\mathrm{M} 1 / \mathrm{M} 2$ & Full axis & 0.716282 & 0.0006 \\
\hline CPF38 & Bos & Dentine (CPF31) & 2122 & 1 & Root & - & 0.710265 & 0.0006 \\
\hline CPF39 & Bos & Dentine (CPF32) & 2123 & 1 & Root & - & 0.711907 & 0.0006 \\
\hline CPF40 & Bos & Dentine (CPF33) & 2140 & 1 & Root & - & 0.713792 & 0.0006 \\
\hline CPF41 & Bos & Dentine (CPF34) & 3008 & 4 & Root & - & 0.710543 & 0.0006 \\
\hline $\mathrm{CPF} 42$ & Bos & Dentine (CPF35) & 3115 & 0 & Root & - & 0.710554 & 0.0006 \\
\hline CPF43 & Bos & Dentine (CPF36) & 610 & 2 & Root & - & 0.710282 & 0.0006 \\
\hline
\end{tabular}

Full axis indicates that samples were taken along the full enamel growth axis of the sampled cusp unit

and rubidium $\left({ }^{87} \mathrm{Rb}\right)$ interferences were monitored and corrected for using ${ }^{83} \mathrm{Kr}\left({ }^{83} \mathrm{Kr} /{ }^{84} \mathrm{Kr}=0.20175\right.$ and ${ }^{83} \mathrm{Kr} /{ }^{86} \mathrm{Kr}=0.66474$; without normalisation) and ${ }^{85} \mathrm{Rb}$ $\left({ }^{85} \mathrm{Rb} /{ }^{87} \mathrm{Rb}=2.5926\right)$, respectively. Analysis of NIST SRM 987 during the analytical session gave a ${ }^{87} \mathrm{Sr} /{ }^{86} \mathrm{Sr}$ value of $0.710292 \pm 0.000014(2 \mathrm{SD}, n=11)$, and all data is corrected 
Table 3 Location, geology and ${ }^{87} \mathrm{Sr} /{ }^{86} \mathrm{Sr}$ isotope results for the six plant samples

\begin{tabular}{lllllll}
\hline Sample & Easting & Northing & Bedrock geology (superficial deposits) & Bedrock age (superficial) & ${ }^{87} \mathrm{Sr}{ }^{86} \mathrm{Sr}$ & $\mathrm{Precision}(2 \mathrm{SE} \%)$ \\
\hline Plant 1 & 338,907 & 188,899 & Blue Lias Formation & Jurassic & 0.710399 & 0.0006 \\
Plant 2 & 338,046 & 190,904 & Brownstones Formation & Devonian & 0.713296 & 0.0005 \\
Plant 3 & 335,717 & 191,034 & St. Maughans Member & Devonian & 0.710561 & 0.0008 \\
Plant 4 & 334,013 & 190,470 & St. Maughans Member (River Terrace deposit) & Devonian (Quaternary) & 0.710205 & 0.0005 \\
Plant 5 & 332,477 & 193,360 & Raglan Mudstone & Silurian & 0.710519 & 0.0005 \\
Plant 6 & 332,961 & 192,984 & Raglan Mudstone & Silurian & 0.713548 & 0.0005 \\
\hline
\end{tabular}

to a NIST SRM 987 value of 0.71024 (Copeland et al. 2008). Total procedural blanks are typically $<1 \%$ of typical sample ${ }^{88} \mathrm{Sr}$ voltages, and measurement of ${ }^{87} \mathrm{Sr} /{ }^{86} \mathrm{Sr}$ in NIST SRM 1400 (bone ash) gave a corrected ${ }^{87} \mathrm{Sr} /{ }^{86} \mathrm{Sr}$ value of 0.71310 , which is identical to published values for this material (Galler et al. 2007).

At the University of Bristol, strontium isotope ratios were measured on a Thermo Finnigan Triton thermal ionisation mass spectrometer (TIMS). Samples were loaded on to rhenium filaments with a $\mathrm{TaCl}_{5}$ activator (Birck 1986). ${ }^{87} \mathrm{Sr}$ measurements were corrected for isobaric ${ }^{87} \mathrm{Rb}$ by monitoring the ${ }^{85} \mathrm{Rb}$ mass and using the ${ }^{85} \mathrm{Rb} /{ }^{87} \mathrm{Rb}$ value of 2.59265 . Samples were corrected for mass fractionation using an exponential mass fractionation law (Russell et al. 1978) and a ${ }^{88} \mathrm{Sr} /{ }^{86} \mathrm{Sr}$ value of 8.375209. All data was corrected to a NIST SRM 987 value of 0.710248 (Avanzinelli et al. 2005). Long-term reproducibility of NIST 987 analyses is $0.710228 \pm 0.000034$ (2 $\mathrm{SD}, n=156)$ and a modern seal tooth $0.70918 \pm 0.000033$ (2 $\mathrm{SD}, n=25)$. Total procedural blanks are on the order of $100 \mathrm{pg}$.

\section{Results}

\section{Defining the locally bioavailable ${ }^{87} \mathrm{Sr} /{ }^{86} \mathrm{Sr}$ range}

Bioavailable strontium in Britain represents a combination of weathered strontium from underlying geology and precipitation (Montgomery 2010). The impact of strontium from rainfall is particularly substantial in areas of high precipitation on the western seaboard. Caerleon is located in an area of high rainfall and is also on the floodplain of the river Usk, and therefore, meteoric and river water would affect bioavailable strontium. In this study, the local ${ }^{87} \mathrm{Sr} /{ }^{86} \mathrm{Sr}$ range was estimated through the analysis of six modern plant samples, each from different locations surrounding Caerleon; seven dentine samples from the Priory Field excavations; as well as published biosphere data. The following discussion of the local range focuses principally on the plant results and is supported by published biosphere data. Dentine values from paired enamel samples are presented and have variable ${ }^{87} \mathrm{Sr} /{ }^{86} \mathrm{Sr}$. This is not surprising, given the range of initial ${ }^{87} \mathrm{Sr} /{ }^{86} \mathrm{Sr}$ of their enamel and that diagenetic uptake of strontium into dentine is likely to be an additive process (Nelson et al. 1986; Conlee et al. 2009; Madgwick et al. 2012). Therefore, even dentine which is at equilibrium with the burial environment $\mathrm{Sr}$ will still have ${ }^{87} \mathrm{Sr} /{ }^{86} \mathrm{Sr}$ values that are a mass balance of the biogenic and diagenetic strontium and need not be isotopically equivalent to the diagenetic strontium. The dentine samples show a reduced range in ${ }^{87} \mathrm{Sr} /{ }^{86} \mathrm{Sr}$ relative to their initial enamel values, and all dentine samples lie on a vector in the ${ }^{87} \mathrm{Sr} /{ }^{86} \mathrm{Sr}$ space towards a diagenetic Sr value in the region of $\sim 0.7103$, which would be consistent with the measured biosphere ${ }^{87} \mathrm{Sr} /{ }^{86} \mathrm{Sr}$ of the site $(0.710205$, plant sample 4). In any case, simply establishing the signal for the precise location of the site is of negligible value in an area with such diverse geology as the south coast of Wales.

The geology around Caerleon is complex, and an interpretation of the range of the locally bioavailable ${ }^{87} \mathrm{Sr} /{ }^{86} \mathrm{Sr}$ must take account of this. The most useful source of data on the local range is the six analysed plant samples. These provide a bimodal distribution between less radiogenic values of approximately $0.7102-0.7106(n=4$, plants $1,3,4$ and 5$)$ and more radiogenic values of 0.7133 to $0.7135(n=2$, plants 2 and 6, see Fig. 2). The wide range in ${ }^{87} \mathrm{Sr} /{ }^{86} \mathrm{Sr}$ defined by these samples broadly matches what should be expected for locally bioavailable Sr. The plant samples do not cover all of the diverse lithologies in the vicinity of Caerleon. None were analysed from the Carboniferous limestone deposits to the east of the site, which are marine-derived sediments and represent a relatively well-known lithology. Evans et al. (2010) quote an average of $0.7092 \pm 0.0002(1 \mathrm{SD}, n=11)$ from plants on Carboniferous limestone in Britain. This is likely to represent the lower limit of bioavailable ${ }^{87} \mathrm{Sr} /{ }^{86} \mathrm{Sr}$ in the vicinity of Caerleon along with the marine-dominated tidal flats deposits on the coast to the south. The upper limit for bioavailable ${ }^{87} \mathrm{Sr} /{ }^{86} \mathrm{Sr}$ in the Caerleon area is defined by the plant measurements from the Silurian and Devonian Old Red Sandstone (ORS) lithologies surrounding the site. ${ }^{87} \mathrm{Sr} /{ }^{86} \mathrm{Sr}$ values of 0.713296 (plant 2) and 0.713548 (plant 6) have been measured for the Brownstones Formation and Raglan Mudstone, respectively. However, the ORS can give a range of bioavailable ${ }^{87} \mathrm{Sr} /{ }^{86} \mathrm{Sr}$ with less radiogenic values of approximately 0.7105 for the St. Maughans Formation and a paired measurement on the Raglan Mudstone. The upper limit 


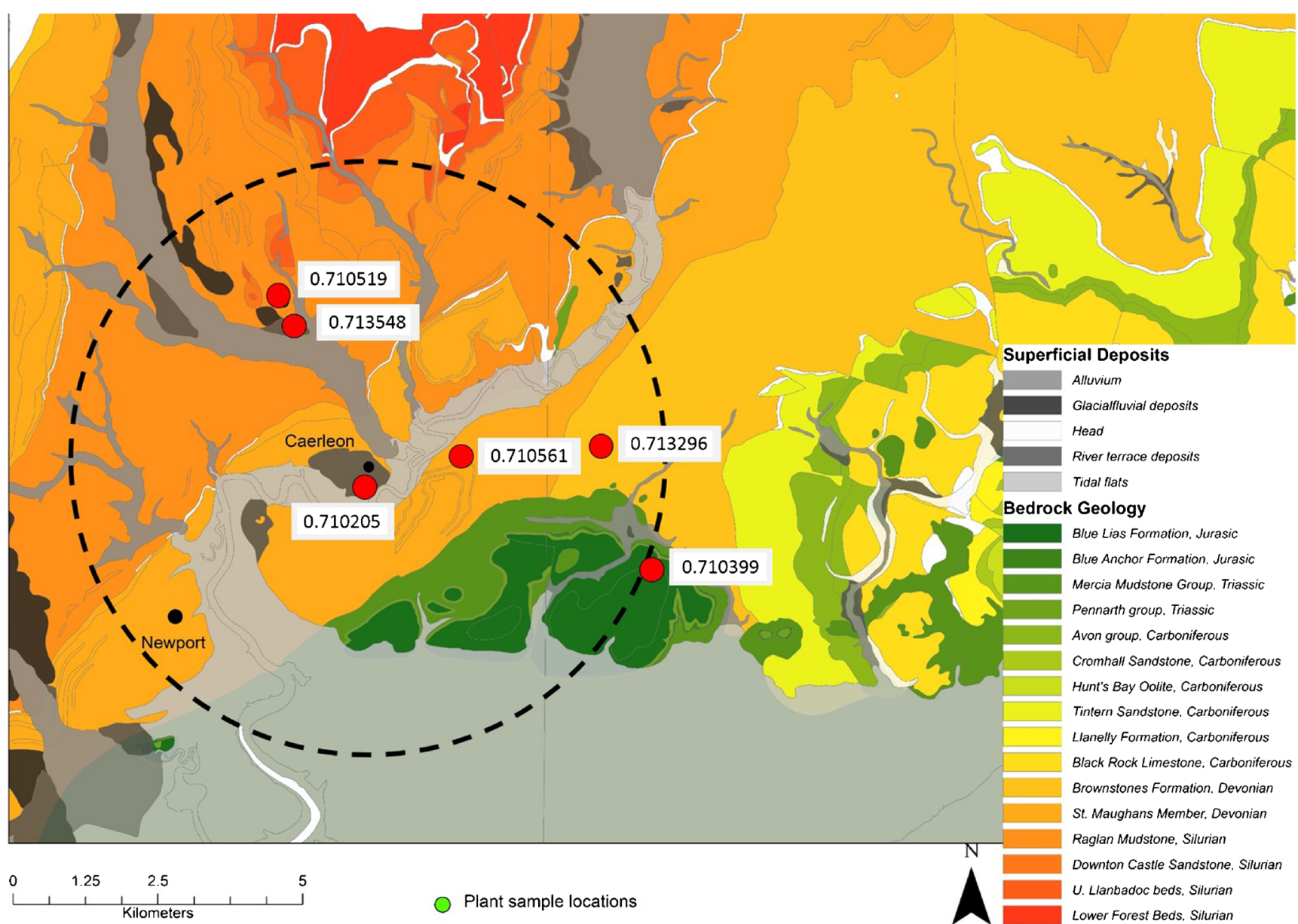

Fig. 2 Map of the Caerleon area with geological overlay and the location and values of the analysed plant samples

of bioavailable ${ }^{87} \mathrm{Sr} /{ }^{86} \mathrm{Sr}$ is therefore estimated to be 0.7136 . The Evans et al. (2010) biosphere map suggests a range of $0.712-0.713$ for the ORS lithology, but this is extrapolated from the sampling of comparable geological areas, rather than being based on local analyses and may underestimate the true range of the locally bioavailable strontium. This represents a cautionary note to an over-reliance on published maps that can rarely achieve comprehensive coverage. It is essential for local biosphere mapping analyses to be combined with archaeological analyses.

The plant results suggest that the ORS is a variable geological unit that can yield a range of bioavailable ${ }^{87} \mathrm{Sr} /{ }^{86} \mathrm{Sr}$ values including radiogenic values in excess of 0.713 , and these very radiogenic values are worthy of further consideration. Squirrel and Downing (1969) give the source for the ORS beds as being the erosion of the Caledonian Mountains, and critically, they note that there is an abundance of mica minerals throughout the ORS succession. Everett et al. (2003) and Kinnaird et al. (2002) have argued, based on $\mathrm{Pb}$ isotope data and detailed mineralogical analysis, that the Caledonian source of the ORS has some input from a granitic material but that this source may not be spatially and temporally consistent. Where bioavailable ${ }^{87} \mathrm{Sr} /{ }^{86} \mathrm{Sr}$ for these granites has been measured in situ, they yield some of the most radiogenic biosphere ${ }^{87} \mathrm{Sr} /{ }^{86} \mathrm{Sr}$ values in Britain (Evans et al. 2010). The presence of some granitic input to the ORS is significant as this material will have abundances of mica and potassium feldspar minerals. Both of these have high $\mathrm{Rb}$ contents and elevated ${ }^{87} \mathrm{Sr} /{ }^{86} \mathrm{Sr}$ (for a given geological age), leading to weathered products (soils) that could lead to the more radiogenic bioavailable ${ }^{87} \mathrm{Sr} /{ }^{86} \mathrm{Sr}$ we observe for ORS sediments.

The plant analysis provided a bimodal distribution, but intermediate values between 0.7105 and 0.7135 may also be produced on ORS sediments in the vicinity. Even if the bimodal distribution is truly representative of the locally bioavailable ${ }^{87} \mathrm{Sr} /{ }^{86} \mathrm{Sr}$, this would not mean that animals with intermediate values could not derive from the Caerleon area. In such a geologically diverse location, it is likely that locally raised cattle and sheep will have grazed on pasture that overlies different lithologies throughout their lives. Similarly, pigs are likely to have been foddered with resources from different areas and driving pigs to wooded areas to exploit seasonal beech mast and feeding them meal scraps would mean their 
biogenic ${ }^{87} \mathrm{Sr} /{ }^{86} \mathrm{Sr}$ would not derive from a single zone. Additionally, in an area of relatively high precipitation such as South East Wales, rainfall could dampen the more radiogenic biosphere values, generating ${ }^{87} \mathrm{Sr} /{ }^{86} \mathrm{Sr}$ values that are intermediate to the bimodal ranges. For these reasons, animal values would be expected to extend across the local range, depending on management and foddering regimes.

Overall, the locally bioavailable ${ }^{87} \mathrm{Sr} /{ }^{86} \mathrm{Sr}$ is estimated to have a lower limit of 0.709 (limited by marine strontium). The upper limit analytically places to 0.7136 , which is conservatively revised to 0.714 . These values can be obtained within a $5-\mathrm{km}$ radius of the site, but the range is likely to encompass a considerably wider local area. It is not possible to define the geographical limits of what is defined as 'local' in this paper, but the range is considered representative of the extended hinterland of the fortress based on the diversity of values and the range of geological units sampled (Fig. 2). This is based on six plant samples and available comparative data, but more comprehensive mapping programmes may mean it will require future revision, particularly given the uncertainty over the ultimate source of the ORS deposits.

\section{The Caerleon fauna}

Results from isotope analysis are presented in Tables 2, 3 and 4 and Fig. 3. The dataset shows a high degree of variation, and ${ }^{87} \mathrm{Sr} /{ }^{86} \mathrm{Sr}$ values consistent with all of the major biosphere packages in Evans et al. (2010) are represented, with the exception of the least radiogenic zone $(0.707-0.708)$ that is present in only very small pockets in western Britain. All three domesticates show a considerable variation, with pigs tending towards more radiogenic values. There is no significant difference in ${ }^{87} \mathrm{Sr} /{ }^{86} \mathrm{Sr}$ isotope values between cattle and sheep (Mann-Whitney $U=69.0, p=0.422$ ) or between cattle and pigs (Mann-Whitney $U=68.0, p=0.230$ ). Pig values were generally more radiogenic than caprines, but the difference narrowly missed statistical significance at 0.05 level (MannWhitney $U=27.5, p=0.053)$. In any case, this difference cannot be considered significant, as multiple pair-wise testing runs the risk of type 1 error, the erroneous rejection of the null hypothesis, and therefore, a Bonferroni corrected significance level (Rice 1989) should be employed (0.017).

Table 4 Mean and 1 SD values for each class of the samples

\begin{tabular}{llll}
\hline & Mean ${ }^{87} \mathrm{Sr}{ }^{86} \mathrm{Sr}$ & $\mathrm{SD}$ & Number \\
\hline Bos & 0.7106 & 0.0019 & 16 \\
Sus & 0.7123 & 0.0022 & 11 \\
Caprine & 0.7101 & 0.0019 & 10 \\
Dentine & 0.7118 & 0.0019 & 7 \\
Plants & 0.7114 & 0.0016 & 6 \\
\hline
\end{tabular}

\section{Discussion}

In many locations in Britain, the diverse results presented here would provide strong evidence for a large proportion of animals being procured from distant areas to support the Roman legions. However, the analysis of just six plant samples from the vicinity of the site demonstrates that the local range of bioavailable ${ }^{87} \mathrm{Sr} /{ }^{86} \mathrm{Sr}$ is both complex and diverse, conservatively estimated to be between 0.709 and 0.714 . Consequently, much of the range of ${ }^{87} \mathrm{Sr} /{ }^{86} \mathrm{Sr}$ in the British biosphere can be found within a $5-\mathrm{km}$ radius of Caerleon. This emphasises the importance of coupling ${ }^{87} \mathrm{Sr} /{ }^{86} \mathrm{Sr}$ isotope analysis of archaeological remains with primary local biosphere data; as such, a wide local range was not anticipated prior to this study. The Evans et al. (2010) biosphere map of the UK is an invaluable resource but should only be treated as a guide and cannot encapsulate the full range of variation at the local level. The potential for such a range of bioavailable ${ }^{87} \mathrm{Sr} /{ }^{86} \mathrm{Sr}$ to be present in such a small area is an important finding of this study, with implications for the interpretation of strontium isotope data.

Strontium isotope analysis is most suited to the identification of non-local animals, but such a wide-ranging local background signature means identifying allochthonous animals in the Caerleon case study is challenging. Locally raised animals are likely to feed on a range of resources and graze on different pastures in the vicinity of the site. Therefore, in this study of animals from Caerleon all faunal values between 0.709 and 0.714 are possibly consistent with a local origin. The values obtained from seven individuals (three caprines, three cattle and a pig, representing $19 \%$ of the total dataset) are, however, not consistent with these animals having been raised in South East Wales. Four of these (two cattle and two caprines) have values between 0.708 and 0.709 that are characteristic of a chalkland origin. Chalk dominates much of southern and eastern England and is one of the best understood lithologies in Britain with respect to its bioavailable ${ }^{87} \mathrm{Sr} /{ }^{86} \mathrm{Sr}$. It is also common in Continental Europe, with chalk beds dominating the Normandy coast. The other three allochthonous individuals have highly radiogenic values ranging between 0.7147 and 0.7163 . Areas of such radiogenic geology are less common in Britain and only a single published plant value from Wales has yielded a value as high as this $(0.7147$ from Silurian mudstone in mid-Wales, Evans et al. 2010). While four similar plant values have been obtained from the Malvern Hills in Worcestershire (Chenery et al. 2010), biosphere values in this range are far more common in Scotland (Evans et al. 2010). Although biosphere mapping data for the continent remains sparse, it is also plausible that Palaeozoic lithologies in Brittany could produce these values (Willmes et al. 2014). Therefore, it is likely that at least four animals were not raised in the vicinity of Caerleon and were transported a substantial distance to provision the legionary fortress. Unfortunately, 


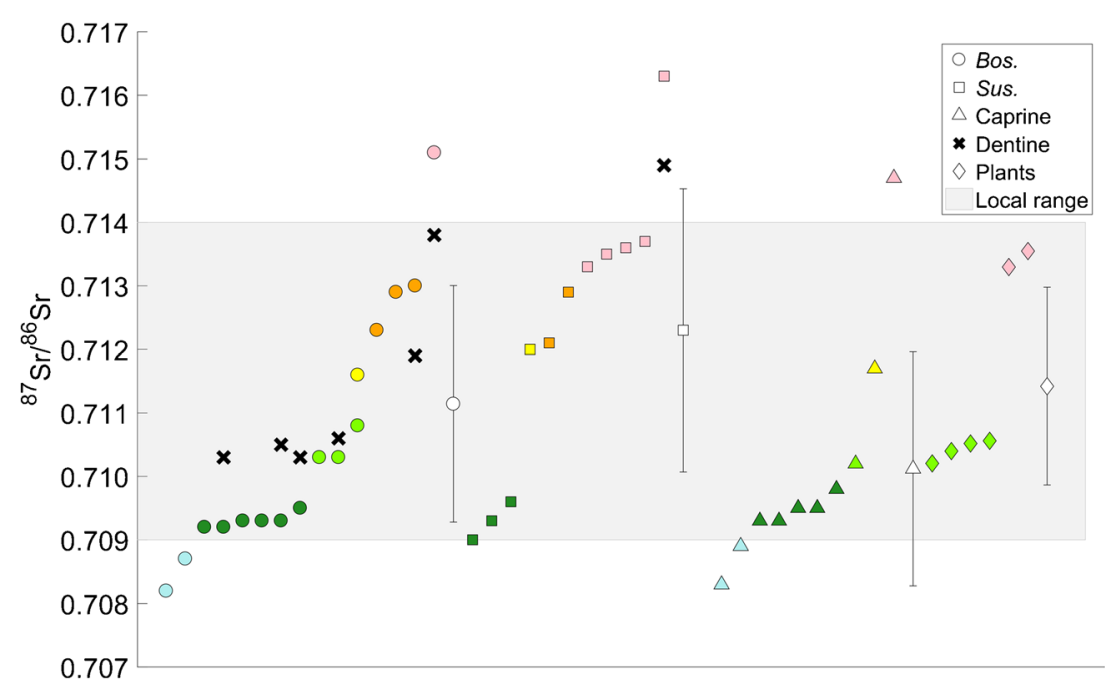

Fig. 3 Strontium $\left({ }^{87} \mathrm{Sr} /{ }^{86} \mathrm{Sr}\right)$ isotope results from the Caerleon Priory Field fauna. Results from the enamel samples are arranged by taxon in ascending order from least to most radiogenic. As a guide, they are colour coded to the published British biosphere map (Evans et al. 2010). The dentine samples are vertically aligned with the corresponding enamel samples. Unshaded markers represent the mean, and error bars indicate the $1 \mathrm{SD}$ range. The shaded area represents the conservative estimate of the local biosphere range (see "Defining the locally bioavailable ${ }^{87} \mathrm{Sr} /{ }^{86} \mathrm{Sr}$ range" for explanation) establishing exactly where the other three possibly allochthonous animals came from is currently beyond the capabilities of the data and a combination of other isotope proxies would be required to further refine their origins.

Nevertheless, these are the first results to demonstrate that some animals, apparently mainly cattle and caprines, were brought to a legionary fortress from outside its immediate region. It is unsurprising that cattle and caprines provide the best evidence for supply from other regions, as pigs are notoriously difficult to herd over distance. Also, it should be emphasised that the results cannot be taken as evidence for the vast majority of animals being raised in the vicinity of Caerleon. As the large bioavailable range encapsulates much of the British biosphere, the data only establishes that a local origin cannot be discounted and it is probable that some of the 30 animals with ${ }^{87} \mathrm{Sr} /{ }^{86} \mathrm{Sr}$ isotope values that fall within the local range also derive from further afield.

Although the sample of analysed animals from Caerleon is modest and is spread across all episodes of Roman occupation, the results show a considerable variation within each stratigraphic phase (see Table 2). This demonstrates that, at the very least, animals were raised in different areas of the landscape surrounding Caerleon (and probably further afield) throughout the period of Roman occupation. It is noteworthy, however, that all seven animals with values outside the local range come from the site clearance or pre-construction dumping that preceded the building of the store at some point between $\mathrm{AD} 90$ and 110 (phase 1ii), although this may result from chance sampling as this phase accounted for more than half of the dataset $(n=21)$.

\section{Conclusion}

This study explores the potential for strontium isotope analysis to provide new insights into the provisioning of animals to the Second Augustan Legion's fortress at Caerleon. The research adds important data to the very limited corpus of strontium isotope results for domestic animals in Roman Britain, providing significant new information on the production, supply and consumption of cattle, sheep/goat and pigs at a key military base. As the first study to use biochemical data to investigate the supply of animals to the Roman army in the provinces, it is hoped that these results will encourage further isotopic studies of husbandry practices and the movement of animals in Roman Britain.

The dataset discussed here provides useful insights concerning patterns of supply to Caerleon, particularly the presence of two groups of non-local animals (a minimum of one in five of the sampled individuals); one suggested to have originated from southern or central England, and the second from northern Britain (or potentially the Malvern Hills or Brittany). Unfortunately, the interpretative resolution of the faunal data considered here is hindered by the surprisingly wide range of bioavailable strontium in the vicinity of the fortress, which means it is difficult to confidently identify non-local animals when much of the range for bioavailable strontium for the whole of Britain can be found within $5 \mathrm{~km}$ of the site. Nevertheless, the identification of seven allochthonous animals is highly likely to 
underestimate the true number of individuals brought to the fortress from a variety of locations beyond its immediate hinterland.

The sample size of just 37 animals is modest and cannot be considered fully representative for Roman Caerleon. However, establishing that a substantial proportion of cattle and sheep/goats consumed by the legion came from considerable distances away is a significant new piece of information with which to further consider the nature of the networks that supplied the army with the animals it needed. It remains to be seen whether the animals were requisitioned from local farmers or were raised by the legion itself, but the diverse pattern of strontium isotope results presented here does not suggest a centralised supply chain based on land around the fortress (or indeed elsewhere).

The sample of six plants from the vicinity of Caerleon also makes an important contribution to the very limited biosphere mapping data for Wales. No previously published plant samples from South East Wales are known to the authors and extrapolating expected results based on the age of local lithologies is no longer considered reliable. The analysis of only six samples established a far greater range of bioavailable strontium in the locality with more radiogenic values than was expected from the lithologies. This highlights the importance of local biosphere mapping data and emphasises that caution must be exercised not only in attempting to establish origins but also in the identification of allochthonous individuals. In short, the potential of provenancing isotope analysis remains stunted by the lack of comprehensive biosphere mapping data.

Overcoming this problem is essential for the advancement of the discipline, but until this is achieved, the use of ${ }^{87} \mathrm{Sr} /{ }^{86} \mathrm{Sr}$ isotope analysis as a lone proxy will remain a coarse tool for determining the origins of animals. Greater precision can be achieved when results are combined with other isotope provenancing indices such as $\delta^{34} \mathrm{~S}$ and $\delta^{18} \mathrm{O}$ as the addition of other isotope proxies should assist in establishing the presence of more non-local individuals and has the potential to refine origins to a greater degree. However, biosphere mapping for $\delta^{34} \mathrm{~S}$ isotopes is still also very poor for Britain and the interpretative and precision issues surrounding the use of $\delta^{18} \mathrm{O}$ isotope data as a provenancing tool are well known (Lightfoot and O’Connell 2016; Pollard et al. 2011; Pellegrini et al. 2016).

Acknowledgements The authors are grateful to Murray Andrews for the assistance with access to the Priory Field faunal archive and to his primary faunal data. Andrew Gardner facilitated the initial TIMS analysis undertaken by JL, and Rebecca Lam is thanked for the assistance with the MC-ICP-MS analyses. Katie Faillace, George Foody and Alison Harris assisted with processing the enamel samples. We are also grateful to Kirsty Harding for the assistance in the production of the figures. Analysis was funded by the Cardiff University Seedcorn Fund.
Open Access This article is distributed under the terms of the Creative Commons Attribution 4.0 International License (http:// creativecommons.org/licenses/by/4.0/), which permits unrestricted use, distribution, and reproduction in any medium, provided you give appropriate credit to the original author(s) and the source, provide a link to the Creative Commons license, and indicate if changes were made.

\section{References}

Andrews M, Lewis J, Powell A (2013) Faunal remains. In: Gardner A, Guest P (eds) Caerleon legionary fortress: excavations in Priory Field \& Golledge's field, 2007-2010. Assessment report. Unpublished assessment report, Cardiff University, pp 39-56

Arnold C, Davies J (2000) Roman and early medieval Wales. Sutton, Stroud

Avanzinelli R, Boari E, Conticelli S et al (2005) High precision Sr, Nd and $\mathrm{Pb}$ isotopic analyses using the new generation thermal ionisation mass spectometer ThermoFinnigan Triton-Ti. Periodico di Mineralogia 75:147-166

Bendrey R, Hayes TE, Palmer MR (2009) Patterns of Iron Age horse supply: an analysis of strontium isotope ratios in teeth. Archaeometry 51:140-150

Bentley RA (2006) Strontium isotopes from the earth to the archaeological skeleton: a review. J Archaeol Method Th 13:135-187

Bentley RA, Knipper C (2005) Geographical patterns in biologically available strontium, carbon and oxygen isotope signatures in prehistoric SW German. Archaeometry 47:629-644

Birck JL (1986) Precision K-Rb-Sr isotopic analysis: application to $\mathrm{Rb}-\mathrm{Sr}$ chronology. Chem Geol 53:73-83

Boon GC (1987) The legionary fortress of Caerleon-Isca. National Museum of Wales, Cardiff

Breeze D (2002) The second Augustan legion in North Britain. In: Brewer R (ed) The second Augustan legion and the Roman military machine. National Museums \& Galleries of Wales, Cardiff, pp 67-82

Budd P, Montgomery J, Barreiro B et al (2000) Differential diagenesis of strontium in archaeological human dental tissues. Appl Geochem 15:687-694

Burnham BC, Davies JL (eds) (2010) Roman frontiers in Wales and the marches. Royal Commission on the Ancient and Historical Monuments of Wales, Aberystwyth

Buzon M, Simonetti A, Creaser R (2007) Migration in the Nile Valley during the New Kingdom period: a preliminary strontium isotope study. J Archaeol Sci 34:1391-1401

Carreras Montfort C (2002) The Roman military supply during the Principate. Transportation and staples. In: Erdkamp P (ed) The Roman army and the economy. Gieben, Amsterdam, pp 70-89

Cavallo C, Kooistra L, Dütting M (2008) Food supply at two successive military settlements in Arras (France): an archaeobotanical and archaeozoological approach. In: Stallibrass S, Thomas R (eds) Feeding the Roman army: the archaeology of production and supply in NW Europe. Oxbow, Oxford, pp 69-82

Chenery C, Eckardt H, Müldner G (2011) Cosmopolitian Catterick? Isotopic evidence for population mobility on Rome's northern frontier. J Archaeol Sci 38:1525-1536

Chenery C, Müldner G, Eckardt H, Lewis M (2010) Strontium and stable isotope evidence for diet and mobility in Roman Gloucester, UK. J Archaeol Sci 37:150-163

Cool H (2006) Eating and drinking in Roman Britain. CUP, Cambridge

Conlee C, Buzon MR, Gutierrez AN et al (2009) Identifying foreigners versus locals in a burial population from Nasca, Peru: an investigation using strontium isotope analysis. J Archaeol Sci 36:2755-2764 
Copeland S, Sponheimer M, le Roux P et al (2008) Strontium isotope ratios $\left({ }^{87} \mathrm{Sr} /{ }^{86} \mathrm{Sr}\right)$ of tooth enamel: a comparison of solution and laser ablation MC-ICP-MS methods. Rapid Commun Mass Sp 22:31873194

Davies RW (1971) The Roman military diet. Britannia II:122-42

Davies J (2004) Soldier and civilian in Wales. In: Todd M (ed) A companion to Roman Britain. Blackwell, Oxford, pp 92-113

Dickson C (1989) The Roman army diet in Britain and Germany. Archäobotanik Dissertations Botanicae 133:135-154

Eckardt H, Booth P, Chenery C et al (2009) Isotopic evidence for mobility at the late Roman cemetery at Lankhills, Winchester. J Archaeol Sci 36:2816-2825

Evans E (2010) Caerleon. In: Burnham BC, Davies JL (eds) Roman frontiers in Wales and the marches. Royal Commission on the Ancient and Historical Monuments of Wales, Aberystwyth, pp $161-172$

Evans JA, Montgomery J, Wildman G et al (2010) Spatial variations in biosphere ${ }^{87} \mathrm{Sr} /{ }^{86} \mathrm{Sr}$ in Britain. J Geol Soc Lond 167:1-4

Everett CE, Rye DM, Ellam RM (2003) Source or sink? An assessment of the role of the Old Red Sandstone in the genesis of the Irish $\mathrm{Zn}-\mathrm{Pb}$ deposits. Econ Geol 98:31-50

Fulford M (2002) The second Augustan legion in the west of Britain. In: Brewer R (ed) The second Augustan legion and the Roman military machine. National Museums \& Galleries of Wales, Cardiff, pp 83-102

Galler P, Limbeck A, Boulyga SF et al (2007) Development of an on-line flow injection $\mathrm{Sr}$ /matrix separation method for accurate, highthroughput determination of $\mathrm{Sr}$ isotope ratios by multiple collector-inductively coupled plasma-mass spectrometry. Anal Chem 79:5023-5029

Gardner A, Guest P (2013) Caerleon legionary fortress: excavations in Priory Field \& Golledge's field, 2007-2010. Unpublished assessment report, Cardiff University, pp 39-56

Groot M (2008) Surplus production of animal products for the Roman army in a rural settlement in the Dutch river area. In: Stallibrass S, Thomas R (eds) Feeding the Roman army: the archaeology of production and supply in NW Europe. Oxbow, Oxford, pp 83-98

Guest P, Gardner A (2017) Excavation of a legionary store-building in Priory Field. Caerleon

Herz P (2002) Die Logistik der kaiserzeitlichen Armee. Strukturelle Überlegungen. In: Erdkamp P (ed) The Roman army and the economy. Gieben, Amsterdam, pp 19-46

Hoppe KA, Koch PL, Furutani TT (2003) Assessing the preservation of biogenic strontium in fossil bones and tooth enamel. Int $\mathrm{J}$ Osteoarchaeol 13:20-28

Horwitz E, Chiarizia R, Dietz ML (1992) A novel strontium-selective extraction chromatographic resin. Solvent Extr Ion Exc 10:313-336

Jarrett M (2002) Early Roman campaigns in Wales. In: Brewer R (ed) The second Augustan legion and the Roman military machine. National Museums \& Galleries of Wales, Cardiff, pp 45-66

Junkelmann M (1997) Panis militaris. Die Ernährung des römischen Soldaten oder der Grundstoff der Macht. von Zabern, Mainz

Kehne P (2007) War- and peacetime logistics: supplying imperial armies in east and west. In: Erdkamp P (ed) A companion to the Roman army. Blackwell, London, pp 323-338

King A (1984) Animal bones and the dietary identity of military and civilian groups in Roman Britain, Germany and Gaul. In: Blagg T, King A (eds) Military and civilian in Roman Britain. British Archaeological Reports British Series 136, Oxford, pp 187-217

King A (1999) Animals and the Roman army: the evidence of animal bones. In: Goldsworthy A, Haynes I (eds) The Roman army as a community. JRA Supplementary Series 34, Rhode Island, pp 139-49

King A (2001) The Romanization of diet in the Western Empire: comparative archaeozoological studies. In: Keay S, Terrenato N (eds)
Italy and the west: comparative issues in Romanization. Oxbow, Oxford, pp 201-223

Kinnaird JA, Ixer RA, Barreiro B et al (2002) Contrasting sources for lead in $\mathrm{Cu}$-polymetallic and $\mathrm{Zn}-\mathrm{Pb}$ mineralisation in Ireland: constraints from lead isotopes. Mineral Deposita 37:495-511

Labisch A (1975) Frumentum Commeatusque: Die Nahrungsmittelversorgung der Heere Caesars. Verlag Hein, Meisenheim an Glan

Leach S, Lewis ME, Chenery C et al (2009) Migration and diversity in Roman Britain: a multidisciplinary approach to immigrants in Roman York, England. Am J Phys Anthropol 140:546-556

Lewis J, Pike AWG, Coath CD et al (2017) Strontium concentration, radiogenic $\left({ }^{87} \mathrm{Sr} /{ }^{86} \mathrm{Sr}\right)$ and stable $\left(\delta^{88} \mathrm{Sr}\right)$ strontium isotope systematics in a controlled feeding study. Sci Technol Archaeol Res 3:53-65

Lightfoot E, O'Connell TC (2016) On the use of biomineral oxygen isotope data to identify human migrants in the archaeological record: intra-sample variation, statistical methods and geographical considerations. PLoS One 11:e0153850

Madgwick R, Mulville J, Evans J (2012) Investigating diagenesis and the suitability of porcine enamel for strontium $\left({ }^{87} \mathrm{Sr} /{ }^{86} \mathrm{Sr}\right)$ isotope analysis. J Anal Atom Spectrom 27:733-742

Maltby M (2016) The exploitation of animals in Roman Britain. In: Millett M, Revell L, Moore A (eds) The Oxford handbook of Roman Britain. OUP, Oxford, pp 791-806

Mason D (1988) Prata Legionis in Britain. Britannia XIX:163-189

Mattingly D (2006) An imperial possession: Britain in the Roman Empire. Penguin, London

McArthur JM, Howarth RJ, Bailey TR (2001) Strontium isotope stratigraphy: LOWESS version 3: best fit to the marine Sr-isotope curve for 0-509 Ma and accompanying look-up table for deriving numerical age. J Geol 109:155-170

Minniti C, Valenzuela-Lamas S, Evans J et al (2014) Widening the market. Strontium isotope analysis on cattle teeth from Owslebury (Hampshire, UK) highlights changes in livestock supply between the Iron Age and the Roman period. J Archaeol Sci 42:305-314

Montgomery J (2010) Passports from the past: investigating human dispersals using strontium isotope analysis of tooth enamel. Ann Hum Biol 37:325-346

Montgomery J, Evans JA, Chenery SR et al (2010a) Gleaming, white and deadly: the use of lead to track human exposure and geographic origins in the Roman period in Britain. In: Eckardt H (ed) Roman diasporas: archaeological approaches to mobility and diversity in the Roman Empire. Journal of Roman Archaeology: Supplementary Series 78, Rhode Island, pp 199-226

Montgomery J, Evans JA, Horstwood MSA (2010b) Evidence for long-term averaging of strontium in bovine enamel using TIMS and LA-MCICPMS strontium isotope intra-molar profiles. Env Archaeol 15:32-42

Montgomery J, Knüsel CJ, Tucker K (2011) Identifying the origins of decapitated male skeletons from 3 Driffield Terrace, York, through isotope analysis. Reflections of the cosmopolitan nature of Roman York in the time of Caracalla. In: Bonogofsky M (ed) The bioarchaeology of the human head: decapitation, decoration, and deformation. University of Florida Press, Florida, pp 141-178

Müldner GH, Chenery C, Eckardt H (2011) The 'headless Romans': multi-isotope investigations of an unusual burial ground from Roman Britain. J Archaeol Sci 38:280-290

Nelson B, DeNiro MJ, Schoeninger MJ et al (1986) Effects of diagenesis on strontium, carbon, nitrogen and oxygen concentration and isotopic composition of bone. Geochim Cosmochim Acta 50:1941-1949

Pearce CR, Parkinson IJ, Gaillardet J et al (2015) Characterising the stable $\left(\delta^{88} /{ }^{86} \mathrm{Sr}\right)$ and radiogenic $\left({ }^{87} \mathrm{Sr} /{ }^{86} \mathrm{Sr}\right)$ isotopic composition of strontium in rainwater. Chem Geol 409:54-60

Pearce J (2002) Food as substance and symbol in the Roman army: a case study from Vindolanda. In: Freeman P, Bennett J, Fiema ZT et al 
(eds) Limes XVIII. Proceedings of the XVIIIth International Congress of Roman Frontier Studies held in Amman, Jordan (September 2000) Volume II. British Archaeological Reports International Series 1084 (II), Oxford, pp 931-944

Pellegrini M, Pouncett J, Jay M et al (2016) Tooth enamel oxygen "isoscapes" show a high degree of human mobility in prehistoric Britain. Sci Rep 6:34986

Pollard AM, Pellegrini M, Lee-Thorp JA (2011) Technical note some observations on the conversion of dental enamel $\delta^{18} \mathrm{O}_{\mathrm{p}}$ values to $\delta^{18} \mathrm{O}_{\mathrm{w}}$ to determine human mobility. Am J Phys Anthropol 145:499-504

Price TD, Blitz J, Burton J, Ezzo JA (1992) Diagenesis in prehistoric bone: problems and solutions. J Archaeol Sci 19:513-529

Price TD, Burton JH, Bentley RA (2002) The characterization of biologically available strontium isotope ratios for the study of prehistoric migration. Archaeometry 44:117-135

Redfern RC, Gr cke DR, Millard AR et al (2016) Going south of the river: a multidisciplinary analysis of ancestry, mobility and diet in a population from Roman Southwark, London. J Archaeol Sci 74:11-22

Reece R (2002) The future of Roman military archaeology. In: Brewer R (ed) The second Augustan legion and the Roman military machine. National Museums \& Galleries of Wales, Cardiff, pp 179-191

Rice WR (1989) Analyzing tables of statistical tests. Evolution 43:223225

Roth J (1999) The logistics of the Roman army at war (264 B.C. - A.D. 235). Brill, Leiden

Russell W, Papanastassiou D, Tombrello T (1978) Ca isotope fractionation on the earth and other solar system materials. Geochim Cosmochim Acta 42:1075-1090

Shaw H, Montgomery J, Redfern R et al (2016) Identifying migrants in Roman London using lead and strontium stable isotopes. J Archaeol Sci 66:57-68

Squirrel HC, Downing RA (1969) Geology of the South Wales Coalfield. Part 1, the country around Newport (Mon.) (explanation of one-inch geological sheet 249, new series), 3rd edn. HMSO, London
Stallibrass S, Thomas R (eds) (2008) Feeding the Roman army: the archaeology of production and supply in NW Europe. Oxbow, Oxford

Stallibrass S (2009) The way to a Roman soldier's heart: a post-medieval model for cattle droving to the Hadrian's wall area. In: Driessen S, Heeren J, Hendriks F et al (eds) TRAC 2008: proceedings of the thirteenth eighteenth annual theoretical Roman archaeology conference. Oxbow, Oxford, pp 101-112

Thomas R (2008) Supply-chain networks and the Roman invasion of Britain: a case study from Alchester, Oxfordshire. In: Stallibrass S, Thomas R (eds) Feeding the Roman army: the archaeology of production and supply in NW Europe. Oxbow, Oxford, pp 31-51

Thomas R, Stallibrass S (2008) For starters: producing and supplying food to the army in the Roman north-west province. In: Stallibrass S, Thomas R (eds) Feeding the Roman army: the archaeology of production and supply in NW Europe. Oxbow, Oxford, pp 1-17

Towers J, Montgomery J, Evans J et al (2010) An investigation of the origins of cattle and aurochs deposited in the Early Bronze Age barrows at Gayhurst and Irthlingborough. J Archaeol Sci 37:508-515

Trickett M, Budd P, Montgomery J et al (2003) An assessment of solubility profiling as a decontamination procedure for the ${ }^{87} \mathrm{Sr} /{ }^{86} \mathrm{Sr}$ analysis of archaeological human skeletal tissue. Appl Geochem $18: 653-658$

Viner S, Evans J, Albarella U et al (2010) Cattle mobility in prehistoric Britain: $\mathrm{Sr}$ isotope analysis of cattle teeth from Durrington Walls (Wiltshire, UK). J Archaeol Sci 37:2812-2820

Whittaker CR (2002) Supplying the army. Evidence fromVindolanda. In: Erdkamp P (ed) The Roman army and the economy. Gieben, Amsterdam, pp 204-234

Willmes M, McMorrow L, Kinsley L et al (2014) The IRHUM (isotopic reconstruction of human migration) database - bioavailable strontium isotope ratios for geochemical fingerprinting in France. Earth System Science Data 6:117-122

Zeder M, Pilaar S (2010) Assessing the reliability of criteria used to identify mandibles and mandibular teeth in sheep, Ovis, and goats, Capra. J Archaeol Sci 37:225-242 